\title{
Design, conduct and challenges of a clinical trial utilizing elastic light scattering spectroscopy in the thyroid
}

\author{
Jennifer Rosen", Hyunsuk Suh, Stephanie Lee, Ousama Aamar, Irving Bigio \\ From 2nd Scientific Meeting of the Head and Neck Optical Diagnostics Society \\ San Francisco, CA, USA. 23-24 January 2010
}

Thyroid cancer is the most common endocrine malignancy. The standard of care in the management of a patient with a thyroid nodule is fine-needle aspiration biopsy (FNA) with cytological evaluation. While 5-10\% of nodules are malignant, 10-25\% of FNAs are indeterminate. Consequently, about twice as many patients undergo surgery for a suspicious lesion that turns out to be benign as undergo surgery for a known malignant lesion. A more accurate molecular and ultrastructural based algorithm would be useful to improve diagnostic accuracy. Noninvasive optical tissue diagnosis mediated by fiber-optic probes can be used to perform non-invasive, or minimally-invasive, real-time assessment of tissue pathology in-situ. Elastic light-scattering spectroscopy (ESS) is a point spectroscopic measurement technique, which is sensitive to cellular and subcellular morphological features. Normal and abnormal tissues can generate different spectral signatures as a result of changes in nuclear size, density, and other sub-cellular features, the optical-spectroscopy equivalent of histopathological readings. ESS is optimal for use in the small-volume area as found in thyroid FNA. An important advantage of ESS is that it provides an objective and quantitative assessment of tissue pathology that may not require on-site special expertise and subjective image interpretation as in conventional histopathology. Here we will describe our experience in the clinical application of elastic scattering spectroscopy in the thyroid.
Published: 29 October 2010

doi:10.1186/1758-3284-2-S1-036

Cite this article as: Rosen et al: Design, conduct and challenges of a clinical trial utilizing elastic light scattering spectroscopy in the thyroid. Head \& Neck Oncology 2010 2(Suppl 1):036.
Submit your next manuscript to BioMed Central and take full advantage of:

- Convenient online submission

- Thorough peer review

- No space constraints or color figure charges

- Immediate publication on acceptance

- Inclusion in PubMed, CAS, Scopus and Google Scholar

- Research which is freely available for redistribution

Submit your manuscript at www.biomedcentral.com/submit
C Biomed Central 